\title{
Dimensions and outcomes of experience quality in tourism: The case of Port wine cellars
}

\author{
Teresa Fernandes*, Mariana Cruz \\ Faculty of Economics, University of Porto, Rua Dr. Roberto Frias, s/n, 4200-464 Porto, Portugal
}

\section{A R T I C L E I N F O}

\section{Article history:}

Received 23 November 2015

Received in revised form

1 May 2016

Accepted 4 May 2016

\section{Keywords:}

Experience quality

Satisfaction

Loyalty

Word-of-mouth

Tourism

Wine

\begin{abstract}
A B S T R A C T
Ever since the notion that consumption has an experiential dimension, experience and its impact on business is receiving increased attention. Therefore, understanding experience quality, its drivers and outcomes becomes crucial, especially when experiences are the core of the service offering such as in tourism. However, research on tourism experiences remains sparse and largely conceptual. We develop a higher-order model of experience quality, validated in the wine tourism industry, outlining relevant dimensions and outcomes. Results support the six-dimensional structure of experience quality and its impact on loyalty, satisfaction and word-of-mouth. Overall, we validate a holistic multi-dimensional measure of experience quality and examine key nomological relationships, with important implications for tourism managers.
\end{abstract}

(c) 2016 Elsevier Ltd. All rights reserved.

\section{Introduction}

In this fast growing experience economy, customers are seeking more variety and customisation than they used to in the past (McColl-Kennedy et al., 2015). Ever since the notion that consumption has an experiential dimension, there is a growing recognition that customers are in search of compelling co-created experiences, with both utilitarian and hedonic components (Sandstrom et al., 2008), involving them emotionally, physically and intellectually (Walls, 2013). Though for years consumer research has assumed a highly rational model of buying behaviour (Hosany and Whitam, 2010), in recent years cognitive models alone were considered inadequate in explaining consumption, which includes both rational and emotional assessments (Klaus and Maklan, 2012). Following the seminal work of Holbrook and Hirschman (1982) and Pine and Gilmore (1998) set out the concept of experience economy as a new era. The authors argue that, since services and goods are becoming increasingly commoditized, businesses should provide meaningful experiences to their customers in order to add value to their offerings (Berry et al., 2002). Much like a theatrical play, experiences occur when a company "intentionally uses services as the stage and the goods as props" in order to create a memorable event (Pine and Gilmore, 1998, p. 98).

Prahalad and Ramaswamy (2004) made an important shift from conceptualizing experiences as focused on the firm, to the

\footnotetext{
* Corresponding author.

E-mail address: tfernandes@fep.up.pt (T. Fernandes).
}

co-creation of experiences through interaction (Akaka et al., 2015). As such, customers can also co-create their own unique experience, becoming an essential part of companies' offerings (Poulsson and Kale, 2004) as co-producers (Walls et al., 2011) and operant resources (Vargo and Lusch, 2006) beyond the staging or orchestration of experiences. Accordingly, companies do not sell (or stage) experiences, but rather provide a basic platform which consumers can use to obtain their own unique experiences (Gentile et al., 2007; Walls, 2013). Recently, consumer experience has been defined as a multidimensional evaluation, where different factors contribute to form a "holistic" view (e.g. Schmitt, 1999; Gentile et al., 2007; Kim et al., 2011), although these dimensions may be difficult to isolate, expensive to orchestrate and beyond the company's control (Tynan and McKechnie, 2009). Besides the multidimensional nature of experience, research also confirms that it can lead to managerial outcomes of interest (Martin et al., 2015). Reflecting the increasing importance of the topic, the Marketing Science Institute highlighted customer experience as a tier-one research priority for 2014-2016 (MSI, 2014).

But in spite of these developments, much of the academic research on customer experiences remains sparse and scattered in a range of research fields (Gentile et al., 2007; Oh et al., 2007; Hosany and Whitam, 2010; Jakkola et al., 2015; McColl-Kennedy et al., 2015). A major limitation has been the lack of academic research on the measurement of customer experience and its underlying dimensions (Carù and Cova, 2003; Hosany and Whitam, 2010; Klaus and Maklan, 2012), which have not yet been extracted, only assumed (Kim et al., 2011). In fact, experience is a 
far broader and less delimited concept than product or service quality. This is particularly true in contexts where experiences are the core of the product or service such as in tourism (Yuan and $\mathrm{Wu}, 2008$ ), where a holistic approach is missing (Quadri-Felitti and Fiore, 2012).

Based on existing models in the literature, the purpose of this study is to validate a higher-order model of experience quality, applied to the tourism industry and using the customer's perspective, and its impact on marketing outcomes. We offer two theoretical contributions to the literature on experiences. First, we empirically examine the validity of a six-dimensional model of experience quality, adopting a holistic perspective of the concept. Secondly, we empirically investigate the influence of experience quality on customer's satisfaction, loyalty intention and advocacy, thus assessing the nomological validity of the construct. The empirical context chosen for the study is the wine tourism industry, namely Port wine cellars, a setting chosen for its highly, yet underresearched, experiential nature. Hedonic services, such as tourism and wineries, are good examples of experiences that are able to generate emotional and experiential reactions (Slatten et al., 2009). Wineries are authentic places (Hall and Mitchell, 2008) with physical characteristics that define an atmosphere favourable to the enhancement of the visitors' experience (Alonso and Ogle, 2008). While visiting a winery, tourists seek for a relationship with the place and want to know more not only about the wine itself, but also about the region and the people (Hall and Mitchell, 2008). During the winery tour, visitors have the chance to interact with the winery staff, with other consumers, and with the ambiance of the winery (Alant and Bruwer, 2004), creating a holistic consumer experience that can largely exceed mere wine-tasting (Mitchell and Hall, 2004). However, academic research on the conceptualisation and measurement of co-created tourism experiences remains sparse (Binkhorst and Dekker, 2009; Manthiou et al., 2014) and, in particular, very few studies (e.g. Carmichael, 2005) attempt to empirically validate it in wine tourism (O'Neill and Charters, 2000), so far limited to wine products and routes (Pikkemaat et al., 2009).

The paper begins by presenting the literature review relevant to this study, followed by the development of research hypotheses. Then we report the main results of a cross-sectional survey designed to examine how visitors of Port wine cellars evaluate experience quality and their future intentions. Finally, we conclude the paper by presenting final conclusions, contributions and suggestions for future research.

\section{The concept of experience and experience quality}

In past years, customer experience has been a key concept in service research and management, including fields such as services marketing, innovation and retailing (Jakkola et al., 2015). The advent of the "experience economy" brought along a research stream dedicated to the understanding of customer experiences (e.g. Carù and Cova, 2003; Poulsson and Kale, 2004; Gentile et al., 2007; Verhoef et al., 2009). The concept suggests that experience is a form of economic offering that creates a competitive advantage, which is difficult to be imitated and replaced (Manthiou et al., 2014). As a result, numerous authors have underlined the relevance of creating 'extraordinary' customer experiences as a strategy to create value, to give companies a sustainable competitive advantage and to foster customers' satisfaction, loyalty and positive word-of-mouth (e.g. Pine and Gilmore, 1998; Berry et al., 2002; Shaw and Ivens, 2005; Backstrom and Johansson, 2006; Naylor et al., 2008; Bolton et al., 2014).

Described as the core of the service offering and as the basis of all business (Lusch and Vargo, 2006), the experience phenomenon has been referred to, often interchangeably, as consumption experience (Bolton et al., 2014), customer experience (Palmer, 2010), and service experience (Helkkula, 2011). The concept of service experience, or experience in a service setting, is an old, but relatively underdeveloped concept in the literature (Dube and Helkkula, 2015). Researchers approach customer experience according to different, but complementary, perspectives (Helkkula, 2011): as a process (focusing on the architectural and time element of the experience); as an antecedent to various outputs (such as satisfaction and repurchase intentions); or as a phenomenon (specific to an individual in a specific context). The phenomenological and holistic approach shifted the focus from the production of outcomes to how they are uniquely and contextually experienced by the individual (Vargo and Lusch, 2004). Experiences have been recognized within Service-Dominant (SD) logic as a key dimension in the value co-creation process, since "there is no value until an offering is used", and thus "experience and perception are essential to value determination" (Vargo and Lusch, 2006, p. 44). Thus, value is no longer embedded in tangible offers, but is co-created with customers and other actors in interactive experiences (Vargo and Lusch, 2004; Helkkula et al., 2012). Accordingly, contemporary thought promotes the idea that experiences are not solely delivered by organizations for customers, but are mainly a function of the personal and subjective value perceived by the actors involved (Helkkula et al., 2012). As a result, the interactive, co-created aspect of customer experience has become a topical issue (Jakkola et al., 2015).

The research perspective has thus evolved from studying 'extraordinary' experiences toward studying experience as a collective, co-created phenomenon, moving away from a dyadic firmcustomer perspective (Frow et al., 2014; Jakkola et al., 2015). Broadly speaking, experience originates from a set of complex interactions between the customer and other actors, including a company or a company's offerings (Carù and Cova, 2003), shaped by their characteristics and influenced by the environment in which the interaction takes place (Walls et al., 2011). In recent research, experiences are seen as omnipresent and as a core element in the emergence of experiential value (Dube and Helkkula, 2015).

As experiences are replacing quality as the "competitive battleground for marketing" (Klaus and Maklan, 2013, p. 227), understanding experience quality and its dimensions becomes crucial. However, very few studies have investigated customers' perceptions of experience quality (Chang and Horng, 2010) or identified and measured its dimensions (Kim et al., 2011): so far, researchers have mainly studied perceived service quality and customer satisfaction (Olsson et al., 2012). In fact, investigations on experience quality have not caught much attention: customer experience has not been analysed as a separate construct nor has it been explored in a theoretical perspective (Verhoef et al., 2009); instead, it has been integrated with service quality studies (Kim et al., 2011).

However, service quality and its most popular measure, SERVQUAL (Parasuraman et al., 1988), are too limited to fully capture customer experience quality (Maklan and Klaus, 2011). In fact, the two assessments are conceptually distinct: service quality is essentially a cognitive and transaction-related evaluation, whereas customers tend to subjectively and emotionally evaluate the experience quality (Chang and Horng, 2010). Customer experience goes beyond service (Klaus and Maklan, 2012) and the contemporary consumer demands more than just competent service, seeking experiences which are emotionally "engaging, robust, compelling and memorable" (Gilmore and Pine, 2002, p. 10). Also, current measures evaluate characteristics of the offering, but not the actual customer experience (Palmer, 2010). Service quality reflects traditional concepts according to which value is embedded 
Table 1

Overview on the relevant literature on the dimensions of experience quality and its measurement.

\begin{tabular}{|c|c|c|c|}
\hline Study & Setting & Dimensions considered & Measure \\
\hline $\begin{array}{l}\text { Knutson et al. (2007) } \\
\text { Kim et al. (2011) }\end{array}$ & Distribution channels & $\begin{array}{l}\text { Environment, benefits, convenience, } \\
\text { accessibility, utility, incentive and trust }\end{array}$ & $\begin{array}{l}\text { Consumer Experience } \\
\text { Index (CEI) }\end{array}$ \\
\hline $\begin{array}{l}\text { Chang and Horng } \\
\text { (2010) }\end{array}$ & Retailing & $\begin{array}{l}\text { Physical surroundings, service providers, other } \\
\text { customers, customers companions, customers themselves } \\
\text { (i.e. cognitive learning and fun) }\end{array}$ & Service Experience Quality \\
\hline $\begin{array}{l}\text { Klaus and Maklan } \\
\text { (2012) }\end{array}$ & Mortgage services & $\begin{array}{l}\text { Product experience, outcome focus, moments of } \\
\text { truth, peace of mind }\end{array}$ & $\begin{array}{l}\text { Service Experience Quality } \\
\text { (EXQ) }\end{array}$ \\
\hline
\end{tabular}

in service offerings, while experiences lead to co-created value with customers through value-in-use (Olsson et al., 2012; Maklan and Klaus, 2011). However, customer experience has been defined so broadly and holistically that it remains an elusive and indistinct concept (Kim et al., 2011), leading to a multiplicity of perspectives (Palmer, 2010; Johnston and Kong, 2011; Dube and Helkkula, 2015), incurring the risk of becoming "the theory of everything" (Maklan and Klaus, 2011). Most studies on customer experience are essentially conceptual or descriptive (Chang and Horng, 2010; Helkkula, 2011) and fail to capture the complexity of contextspecific variables and its impact on experience quality and marketing outcomes (Palmer, 2010; Lemke et al., 2011). As such, and considering that customer experience is a priority for organizations, its measure from the customer's point of view needs to be addressed (Klaus and Maklan, 2012). This is particularly true in contexts where experiences are the core of the product or service such as in tourism (Yuan and Wu, 2008).

\section{Experience and experience quality in tourism}

Tourism companies are increasingly focusing on creating and managing experiences for their customers (Walls et al., 2011; Tung and Ritchie, 2011). In essence, tourists do not simply buy products and services; rather, they primarily seek and consume engaging experiences (Oh et al., 2007). Hedonic services, such as the tourism industry, are classic examples of "extraordinary" experiences (Arnould and Price, 1993; Carù and Cova, 2003), i.e. out-of-ordinary experiences that happen outside daily routine (Walls et al., 2011), and are able to generate cognitive and emotional reactions (Slatten et al., 2009). Even experiences regarded as extensions of daily routines (e.g. accommodation or transport) are itself a part of the total tourism product (Quan and Wang, 2004). Thus, tourism is essentially a marketplace of experience, and tourists provide the "mental places" where the experience happens (Volo, 2009). In this sense, everything tourists go through "is an experience" (Oh et al., 2007, p. 120), and thus it is challenging to capture all its different dimensionalities in a structured way (Quan and Wang, 2004). Walls et al. (2011) developed a conceptual framework of tourism experience and acknowledge its multidimensionality, while including physical elements, human interactions, consumer characteristics and situational factors that operate in a unique way for each individual. Accordingly, a tourist experience may be defined as "a blend of many individual elements that come together and may involve the consumer emotionally, physically and intellectually" (Walls, 2013, p.179). However, these dimensions and their relative weight in experience enhancement is still not clear (Walls et al., 2011), despite the growth of the literature on the tourist experience.

In fact, tourism is one of the pioneer examples of experience research, with tourist experiences becoming one of the most popular academic topics in the literature from the 1970s onwards (Quan and Wang, 2004; Hosany and Whitam, 2010). Recently, an increasing number of studies focused in particular on the outcomes of tourist experiences and its measurement (Kim et al., 2012). Oh et al. (2007) applied Pine and Gilmore's (1998) framework and validated that the four realms of experience (aesthetic, education, entertainment, and escapism) measured tourist experiences in the $\mathrm{B} \& \mathrm{~B}$ lodging setting. The same framework was applied to cruise experiences (Hosany and Whitam, 2010) and music festivals (Manthiou et al., 2014). Kim et al. (2012) developed a memorable tourism experience scale, comprising seven dimensions (hedonism, novelty, local culture, refreshment, meaningfulness, involvement, knowledge). These conceptualizations take into account the outcome of the tourist experience, namely how individuals feel when they are participating in tourism activities and their subjective responses, but do not focus on the dimensions of experience quality (Quan and Wang, 2004; QuadriFelitti and Fiore, 2012). In fact, experiential research in the tourism industry has been mainly based on ontological philosophical assumptions about what experiences do to consumers (i.e. emotionally, physically and intellectually), but further empirical research is needed to identify the specific dimensions of consumer experience (Quan and Wang, 2004; Walls, 2013). Though a few studies are available in related areas (Table 1 ), in hospitality and tourism research a holistic approach is missing (Quadri-Felitti and Fiore, 2012).

According to Berry et al. (2002), organizations which fail to fully understand experience dimensions will face disappointing results. This is particularly true for tourism organizations, and thus, identifying tourism experiences and its components within certain settings would be highly relevant to tourism related businesses (Walls et al., 2011). The current study aims to fill this gap, by focusing on what specific dimensions comprise the primary structure of experience quality in a tourism setting. We expect that positive experiences may result in positive satisfaction, recommendation and loyalty behaviours.

\section{Research framework and hypothesis}

The purpose of our research is to develop and test a higherorder model of experience quality, applied to the tourism industry, outlining relevant dimensions and outcomes. Following previous studies (Jarvis et al., 2003; Klaus and Maklan, 2012), our research framework (Fig. 1) specifies experience quality as a formative latent construct, determined by the six reflective dimensions of the model, presented next.

The multidimensional framework adopted was developed based on selected elements that were common to the literature review on customer experience. As such, to define experience quality dimensions, we have considered both functional and emotional components (Sandstrom et al., 2008), adapting them in order to fit the study setting. In fact, as suggested by Lemke et al. (2011), the customer experience and its measurement are of context-specific nature and, therefore, need to be explored in one 


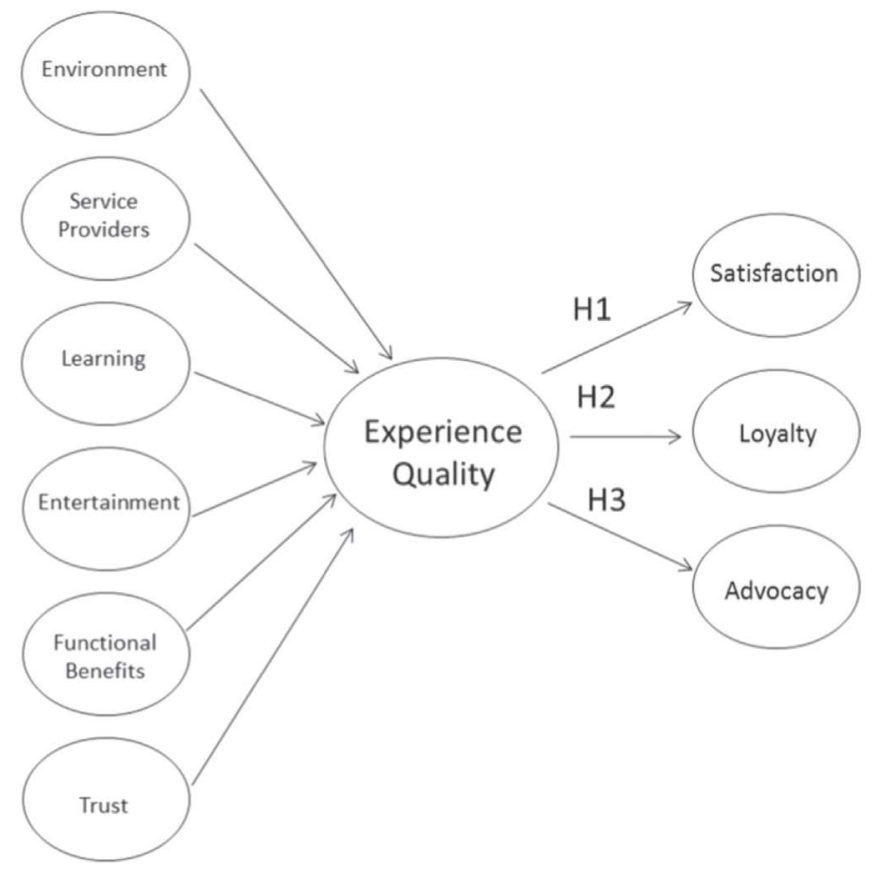

Fig. 1. Research framework.

specific setting (Ponsignon et al., 2015). A set of items was initially generated from a review of previous research pertaining to experience quality. Six dimensions were selected: Environment, Service Providers, Learning, Entertainment, Functional Benefits and Trust (Appendix 1). According to Chang and Horng (2010), customers are commonly more impressed by settings with atmosphere, and physical surroundings may elicit positive customers' emotional perceptions of experience quality. This dimension was found to be especially significant for customers' experience of hedonic services (e.g. Slatten et al., 2009). Also, much research has been devoted to understanding the role of the employee in the delivery of experience (Slatten et al., 2009). Service employees have the potential to influence the value-creating experience by interacting with the customer (Sandstrom et al., 2008; Walls, 2013) and can play a crucial part in the quality of the tourist's experience (O'Neill and Charters, 2000). In terms of learning, educational experiences engage the minds of consumers and appeal to their desire to "learn something new", which is especially true in the tourism industry (Hosany and Whitam, 2010). As for entertainment, it is probably one of the oldest forms of experience (Pine and Gilmore, 1998) and remains an essential component of the tourist product. The Functional Benefits dimension aims to reflect practical or functional experience outcomes, such as performance, consistency, and customization/adaptability (Knutson et al., 2007). The experience should fit the purpose for which it was designed in an efficient, convenient and hassle free manner (Kim et al., 2011), including tourist experiences (Volo, 2009). Finally, trust in the individuals providing the service experience reflects the emotional benefits customers experience based on the perceived expertise of the service provider (Klaus and Maklan, 2012) and the feeling of security based on the belief of favourable and positive intentions of the exchange partner; thus, trust corresponds to perceived reliability and benevolence (Morgan and Hunt, 1994), and is at the basic level of human interaction in providing an experience (Kim et al., 2011). As such, we define customer experience quality as a multidimensional higher-order construct, corresponding to a six-factor structure consisting of Environment, Learning, Entertainment, Service Providers, Functional Benefits and Trust.
We also aim to assess the impact of experience quality on important marketing outcomes, such as tourist's satisfaction, loyalty and referrals. In fact, a well-staged experience shapes tourists' attitudinal evaluations, such as satisfaction and future intentions (Oh et al., 2007; Walls, 2013). Service research has validated the impact of quality on behavioural intentions, either directly or indirectly via customer satisfaction (Klaus and Maklan, 2013). Oliver (1997) argues that satisfaction is a customer "fulfilment response", a post-purchase phenomenon that portrays how much the customer likes or dislikes the service. In the context of touristic experiences, satisfaction is usually conceptualized as a function of whether visitors' expectations or their psychological needs are met (Han et al., 2009). Customer satisfaction is also known as an emotional response to direct product experiences (Han and Back, 2007; Bagdare and Jain, 2013). Customer experience also drives word-of-mouth referrals (Kenningham et al., 2007; Tung and Ritchie, 2011) and loyalty (Lemke et al., 2011; Manthiou et al., 2014). According to Naylor et al. (2008) and Frow and Payne (2007), delivering perfect customer experiences can be an opportunity to promote customer advocacy, and to foster customers' satisfaction and loyalty. However, the relationship between experience, satisfaction and behavioural intentions remains unsubstantiated (Hosany and Whitam, 2010). Accordingly, we hypothesise that a pleasant tourist experience has a positive impact on satisfaction, intention to revisit and to recommend:

Hypothesis 1 (H1). Experience quality has a positive impact on customers' satisfaction.

Hypothesis 2 (H2). Experience quality has a positive impact on customers' loyalty.

Hypothesis 3 (H3). Experience quality has a positive impact on customers' advocacy.

The setting chosen for this study was wine tourism, namely the cellar door experience. This was considered a desirable setting given that wineries have the potential to offer memorable and holistic tourist experiences that can largely exceed mere winetasting (O'Neill et al., 2002; Mitchell and Hall, 2004). Also, increasingly tourists search for more than just a standard tour, and prefer "experience-intensity and life-hype" (Pikkemaat et al., 2009, p. 237). According to the authors, wine tourism fulfils these new customer requirements by providing "authentic wine experiences" (p. 238). Wine tourism is defined as "the visitation to vineyards, wineries, wine festivals and shows, for which wine tasting and/or experiencing the attributes of a wine region are the prime motivating factors for visitors" (Hall, 1996, p. 1). Although wine tourism covers other services, such as tours, festivals or accommodation, wine tourism focuses on cellar doors or wineries. Given the competitive nature of the wine industry, wineries are expanding their offerings in order to attract visitors, including e.g. lodging facilities or restaurants. Added value elements such as friendly and knowledgeable staff members, a cosy and intimate atmosphere or an accessible and well-designed layout all contribute to the quality of the cellar door experience (O^Neill and Charters, 2000). Thus, the cellar door is a self-contained setting that, besides from showcasing the winery's products, offering wine-tasting experiences and increasing wine sales, may be an opportunity to develop long lasting relationships between producers and visitors (Nowak and Newton, 2006; Fountain et al., 2008).

\section{Research methodology}

Visitors of three Port wineries, chosen based on the extensive cellar door service offered, served as the study population. Wine 
tourism has emerged as a strong and growing area of special interest of tourism in Portugal. This development is particularly significant within the Northern region, where the Douro Valley is fast becoming a popular worldwide wine tourism destination, with a number of accommodation facilities, vineyards and wineries to attract visitors, and has now an international reputation for its wines, namely Port wine.

The survey instrument consisted of a self-administrated, paperbased questionnaire referring to customers' demographics, experience evaluation and subsequent behavioural intentions. Data collection was similar to a mall-intercept method: randomly chosen visitors of three Port wine cellars were requested to voluntarily participate in the survey and to fill out the questionnaire on site, resulting in 290 usable responses. Respondents were surveyed before the final wine tasting, just after the visit to the cellars was completed, minimising bias associated with retrospective recall. Data were collected over a two-week period during peak season, with the assistance of cellars staff, who were given explicit instructions on how to brief the respondents: the specific research objectives were not revealed and respondents were given around $10 \mathrm{~min}$ to complete the survey. Besides demographic data, the questionnaire comprised 30 questions regarding experience quality dimensions, satisfaction, advocacy and loyalty intentions. The measures were established scales from previous studies, adapted to fit the study setting. The set of items was reviewed by a panel of researchers, wine makers and registered customers to ensure content validity. With the exception of the questions regarding consumer characteristics, all items employed seven-point Likert scales. "Environment" was measured with 4 items from Chang and Horng (2010) and the Consumer Experience Index (CEI) model (Kim et al., 2011). "Service Providers" was measured with 3 items from Chang and Horng (2010) and the Experience Quality (EXQ) scale (Klaus and Maklan, 2012). "Learning" and "Entertainment" measures were based on Chang and Horng (2010). "Functional Benefits" was measured with 4 items from the CEI model, while "Trust" was measured with 4 items from CEI and EXQ scales. Following the EXQ model, "Satisfaction" was measured with 3 items from Dagger et al. (2007); "Loyalty" was measured with 3 items from Parasuraman et al. (2005); and to measure "Advocacy", 3 items from Brown et al. (2005) were used. To measure experience quality and its impact on marketing outcomes, Partial Least Squares Structural Equation Modelling (PLS-SEM) using the SmartPLS 3.0 software (Ringle et al., 2012) was employed. PLSSEM is explicitly recommended for models including formative measurement constructs and readily incorporates both reflective and formative measures (Hair et al., 2014). The higher-order construct of experience quality was modelled formatively by using the hierarchical components or repeated indicators approach (Wold, 1982), where the indicators of the six lower-order reflective dimensions are repeated to measure the higher-order formative construct (Ringle et al., 2012). The advocated two-step procedure of evaluating the measurement (outer) model first, followed by an estimation of the structural (inner) model was followed (Diamantopoulos and Winklhofer, 2001). Main results are shown in the following section.

\section{Research findings}

The majority of the respondents (51\%) were male, ageing between 20 and 40 years old (59\%), mainly French (22\%) or Spanish (20\%) tourists, and who had never visited a Port wine cellar before (69\%). Respondents were equally divided among the three cellars (with approximately $1 / 3$ of the respondents each).

The psychometric properties of the multiple items scale were assessed through multiple indices (Table 2). Composite measures of identified factors of both experience quality dimensions and marketing outcomes were unidimensional and demonstrated good scale reliability according to accepted standards (Nunnally, 1978). One of the items measuring loyalty reduced scale reliability and was thus removed. Internal reliability tests of the identified factors showed strong Cronbach's alpha (ranging from .610 to .819), Composite Reliability (CR) and Average Variances Extracted (AVE), with all CR and AVE estimates above recommended minimums of .70 and .50, respectively (Fornell and Larcker, 1981; Bagozzi and Yi, 1988; Hair et al., 2010). Thus, all the factors demonstrated good internal consistency and high levels of convergence, supporting the reliability and validity of our multiple items scale.

Convergent and discriminant validity were demonstrated by factor loadings and correlations between experience quality dimensions, respectively. All factor loadings for indicators measuring the same construct were statistically significant $(p<.01)$, supporting convergent validity. Moreover, estimated pair-wise correlations between factors (i) did not exceed .85 and were significantly less than one (Bagozzi and Yi, 1988); and (ii) the square root of AVE for each construct was higher than the correlations between them (Fornell and Larcker, 1981), thus supporting discriminant validity (Anderson and Gerbing, 1988). Table 3 shows the means, reliabilities and correlations between the constructs.

After establishing the strength and psychometric properties of the scales underpinning the model, we examined the degree of multicollinearity among the six dimensions defined as experience quality components, as suggested for formative measurement constructs. When excessive multicollinearity exists between the formative indicators, the formative nature of the higher-order construct may be inappropriate (Diamantopoulos and Winklhofer, 2001). As such, the variance inflation factor (VIF) for each indicator was determined. Values vary from 1.921 to 3.238 , which is below the common cut-off threshold of 5 (Hair et al., 2014), thereby suggesting that the factors are not highly correlated to one another. Therefore, the six dimensions were retained in the model measurement model (Fig. 2). The weights of the six components of experience quality and their significance were also examined. All weights are significant, which supports the relevance of the six indicators for the construction of the formative, higher-order construct of experience quality (Hair et al., 2014). Furthermore, all weights are higher than .1 and their signs are all positive, consistent with the underlying theory (Andreev et al., 2009). Functional Benefits (.269) and Environment (.245) emerged as the most important components of customers' evaluation of experience quality. Entertainment (.138) and Learning (.149) were viewed as the least important factors. Giving the above findings, we conceptualize customer experience quality as a multidimensional, formative, higher-order construct, comprised of six reflective dimensions (Environment, Service Providers, Learning, Entertainment, Functional Benefits and Trust).

As for nomological validity, we further conducted a structural (inner) model to examine whether customers' perceived experience quality had an effect on theoretically related constructs (Diamantopoulos and Winklhofer, 2001), namely customers' satisfaction, loyalty and advocacy. The quality of PLS models is evaluated based on the direction and significance of path coefficients and the magnitude of variance in a construct explained by the model. The standardized path coefficients and significance levels provide evidence of the structural model's quality (Hair et al., 2014). The coefficient values of all paths were significant at $\mathrm{p}<.01$. Experience quality explained $72 \%$ of customer satisfaction variance, $35 \%$ of customer loyalty and $64 \%$ of customer advocacy (Fig. 2). Structural parameters for experience quality, satisfaction, loyalty and advocacy paths demonstrate that experience quality has a direct effect on satisfaction (.85), loyalty (.59) and advocacy (.80). Thus, predictive validity of the model was achieved, and 
Table 2

Measurement scales, reliability and dimensionality statistics.

\begin{tabular}{|c|c|c|c|}
\hline Measures & Loadings & Means & $\mathrm{CR}(\mathrm{AVE})$ \\
\hline Environment $(\alpha=.752)$ & & & $.857(.600)$ \\
\hline The environment of the wine cellar is enjoyable & .820 & 6.37 & \\
\hline The environment of the wine cellar is stimulating to the senses & .772 & 6.03 & \\
\hline I am surprised with the wine cellar environment & .729 & 5.45 & \\
\hline The atmosphere of the wine cellar has an impact on my state-of-mind & .773 & 5.76 & \\
\hline Service providers $(\alpha=.698)$ & & & $.837(.632)$ \\
\hline Service employees of the wine cellar serve me friendly and kindly & .772 & 6.71 & \\
\hline The people at the wine cellar have good interpersonal skills & .812 & 6.51 & \\
\hline Interacting with service providers makes me feel that I'm treated with respect & .801 & 6.43 & \\
\hline Learning $(\alpha=.610)$ & & & $.796(.564)$ \\
\hline The guides and brochures help me to learn and understand the topics & .801 & 6.37 & \\
\hline I have obtained more knowledge about Port Wine and the winery brand & .748 & 6.31 & \\
\hline I've learned something new about Port Wine after visiting this wine cellar & .701 & 6.30 & \\
\hline Entertainment ( $\alpha=.627$ ) & & & $.844(.729)$ \\
\hline This is a wine cellar where people can enjoy themselves & .847 & 6.18 & \\
\hline It is happy time when I visit this wine cellar & .861 & 6.18 & \\
\hline Functional benefits ( $\alpha=.794)$ & & & $.869(.618)$ \\
\hline The wine cellar service is tailored to the visitors & .802 & 6.14 & \\
\hline The wine cellar service level is of value to me & .766 & 6.09 & \\
\hline Consistency in the wine cellar service assures me a benefit & .794 & 5.96 & \\
\hline The visit to the wine cellar is well organized & .785 & 6.20 & \\
\hline Trust $(\alpha=.785)$ & & & $.861(.609)$ \\
\hline The wine cellar belongs to a safe and reputable brand & .760 & 6.32 & \\
\hline My satisfaction with the wine cellar products/services is the management's most important concern & .818 & 6.20 & \\
\hline I'm confident in the wine cellar expertise & .761 & 6.32 & \\
\hline My satisfaction with the wine cellar brand is the management's most important concern & .781 & 6.17 & \\
\hline Satisfaction $(\alpha=.770)$ & & & $.859(.605)$ \\
\hline I feel good about coming to the wine cellar for the offerings I'm looking for & .768 & 6.18 & \\
\hline My feelings towards the wine cellar are very positive & .816 & 6.31 & \\
\hline The extent to which the wine cellar has produced the best possible outcome for me is satisfying & .740 & 6.09 & \\
\hline Overall I'm satisfied with the wine cellar and the service they provide & .784 & 6.55 & \\
\hline Loyalty $(\alpha=.624)$ & & & $.850(.739)$ \\
\hline I consider this wine cellar my first choice among wineries & .854 & 5.97 & \\
\hline I would consider to visit the wine cellar again in the next few years & .865 & 5.23 & \\
\hline Advocacy $(\alpha=.819)$ & & & $.893(.737)$ \\
\hline I would recommend the wine cellar to someone who seeks my advice & .852 & 6.30 & \\
\hline I would recommend the wine cellar to family members and close personal friends & .895 & 6.32 & \\
\hline I would speak positively of the wine cellar to others & .826 & 6.55 & \\
\hline
\end{tabular}

Table 3

Means, reliabilities and correlations between the dimensions of experience quality.

\begin{tabular}{|c|c|c|c|c|c|c|c|c|c|c|}
\hline Dimensions & Mean & $\alpha$ & $\mathbf{C R}^{\mathrm{a}}$ & $\mathbf{A V E}^{\mathrm{b}}$ & Environment & Providers & Learning & Entertainment & Benefits & Trust \\
\hline Environment & 5.93 & .752 & .857 & .600 & 1 & & & & & \\
\hline Providers & 6.55 & .698 & .837 & .632 & $.497^{\mathrm{C}}$ & 1 & & & & \\
\hline Learning & 6.33 & .610 & .796 & .564 & .449 & 609 & 1 & & & \\
\hline Entertainment & 6.18 & .627 & .844 & .729 & .540 & .586 & .578 & 1 & & \\
\hline Benefits & 6.09 & .794 & .869 & 618 & .679 & .663 & .591 & .583 & 1 & \\
\hline Trust & 6.25 & .785 & .861 & .609 & .591 & .680 & .524 & .503 & .672 & 1 \\
\hline
\end{tabular}

${ }^{\text {a }}$ Composite reliability.

b Average Variance Extracted.

${ }^{\mathrm{c}}$ Correlations on the off-diagonal; $\mathrm{p}<.01$ for all correlations. 


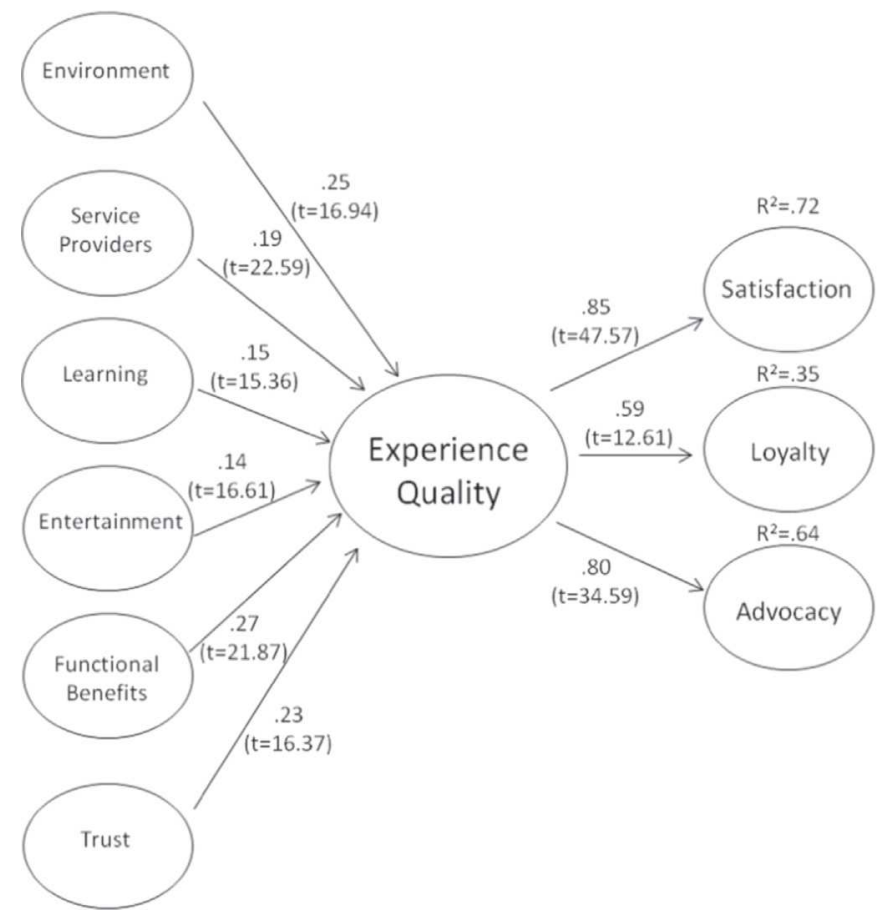

Fig. 2. PLS results for the higher-order model of experience quality. and nomological validity assessment (all path coefficients significant at $\mathrm{p}<.000$ ).

hypotheses H1-H3 were confirmed. Next, the results of our study are discussed.

\section{Discussion and conclusions}

Because of today's advanced technology, more sophisticated and demanding customers, the focus is shifting from a servicebased to an experience-based economy (Knutson et al., 2007; Kim et al., 2011) as a new source of competitive advantage (Prahalad and Ramaswamy, 2004). However, few studies have analysed experience quality, and even fewer related it to consumer behavioural intentions. This void is particularly noticeable in tourism research: despite considerable research on the topic of "tourist experience" and its relevance to the hospitality industry (Gilmore and Pine, 2002; Tung and Ritchie, 2011), little empirical evidence can identify and measure its dimensions and outcomes (Knutson et al., 2007; Walls, 2013).

The purpose of this research was twofold: to test a higher-order model of experience quality, validated in the wine tourism industry; and to analyse its impact on important marketing outcomes. The wine tourism setting remains relatively under-studied and, as a result, calls for further research in understanding tourists' experiences and post-consumption evaluations. Overall, the six dimensions of experience quality were validated, with Functional Benefits and Environment having the most significant contribution to experience quality. Recent studies have also established the significant impact of these elements on experience quality (e.g. Charters et al., 2009; Hosany and Whitam, 2010; Kim et al., 2011; Klaus and Maklan, 2012). However, Functional Benefits and Environment recorded the lowest means in our study. Though better rated, the Entertainment and Learning dimensions were viewed as the least important components of experience quality. These findings contrast with e.g. Chang and Horng (2010) study, wherein customers themselves (through learning and having fun) had one of the most significant impact on customers' assessments. Also,
Getz and Carlsen (2008) labelled the fun, informative, and social aspects of wine tourism as "edutainment" (p. 262). In fact, learning and entertainment are an integral part of wine tourism and often wine is embedded in a variety of events and attractions (Mitchell and Hall, 2004; Carmichael, 2005; Quadri-Felitti and Fiore, 2012). Given the specificity of the findings to one particular setting, further studies are required to re-evaluate the role of Learning and Entertainment in creating positive memorable experiences within wineries.

In line with Chang and Horng (2010), Kim et al. (2011) and Klaus and Maklan (2012) recommendations for additional research, a secondary aim of this study was to investigate the relationship between visitor's experiences and relevant marketing outcomes. We have concluded that experience quality has a significant impact on customers' loyalty, advocacy and satisfaction. Thus, wineries should create pleasant experiences in order to generate higher satisfaction levels and to positively influence visitors' behavioural intentions. Since tourists rely heavily on noncommercial sources of information, such as recommendations from friends and family (Hosany and Whitam, 2010), memorable experiences may not only impact the intention to revisit, but also to bring new customers to the wineries.

Theoretically, our results offer a holistic multi-dimensional view of experience quality and validate the nomological network of the construct. In managerial terms, our findings allow winery managers to improve the overall experience quality through a better understanding of its dimensions. Managers can also determine which experience dimensions are most strongly associated with customer-related outcomes and, thus, improve the effectiveness of marketing investments. For example, though considered the most relevant factor for assessing visitor's experience quality, Functional Benefits had the second lowest mean of all the dimensions considered, which may raise some questions about how this dimension is being managed. A similar result was observed with Environment, which was expected to enhance visitors' winery experience (Alonso and Ogle, 2008). Namely, the ability of the wineries' environment to generate surprise and impact the visitors' state-of-mind had the lowest scores of all the items considered (5.45 and 5.76 respectively), and should deserve more attention as key elements of experience (Poulsson and Kale, 2004). Finally, wineries were highly rated in terms of Service Providers, and for visitors this seems to be one important factor for building a quality experience (O`Neil and Charters, 2000), which might guide a correct allocation of resources.

One limitation of this study is that it focuses on a particular setting, point of time, country, and customer sample. Future research should further cross validate our results in order to increase the study generalisability. For instance, cross-cultural differences may influence the evaluation of experiences, especially considering the cultural-rich context of wineries, and this may provide added insights to the co-creation of value-in-cultural-context (Akaka et al., 2015). Furthermore, McColl-Kennedy et al. (2015) suggest the need to study experience dynamics by understanding customers' evaluations of their experiences over time. Future studies should gather longitudinal information during the customer experience in order to measure the various stages of the customer journey. Also, our research could be extended to include other dimensions and outcomes. For example, the scope of the present study was limited to one facet of interaction, namely between service providers and customers. Since literature increasingly emphasizes the role of customer-to-customer interactions (Ponsignon et al., 2015), the interaction between customers sharing the same service could also be examined. Furthermore, qualitative based studies, combined with quantitative measures, could be effectively combined in order to understand why visitors value certain experience dimensions more than others. Namely, 
phenomenological methods including primarily observations supplemented with customer narratives, diaries and interviews could provide a deeper understanding of how customers make sense of their experiences (Helkkula et al., 2012). Overall, our findings enhance knowledge on the experiential concept and offer important implications for tourism managers.

\section{Appendix 1. Measures of study constructs}

The scale items below are grouped by dimensions for expositional convenience; they appeared in random order in the survey.

\section{Dimensions \\ Environment}

Service

Providers

Learning

Entertainment

Functional

Benefits

Trust

Satisfaction

Loyalty

Advocacy

\section{Items}

The environment of the wine cellar is enjoyable

The environment of the wine cellar is stimulating to the senses

I am surprised with the wine cellar environment

The atmosphere of the wine cellar has an impact on my state-of-mind

Service employees of the wine cellar serve me friendly and kindly

The people at the wine cellar have good interpersonal skills

Interacting with service providers makes me feel that I'm treated with respect

The guides and brochures help me to learn and understand the topics

I have obtained more knowledge about Port Wine and the winery brand

I've learned something new about Port Wine after visiting this wine cellar

This is a wine cellar where people can enjoy themselves

It is happy time when I visit this wine cellar

The wine cellar service is tailored to the visitors

The wine cellar service level is of value to me

Consistency in the wine cellar service assures me a benefit

The visit to the wine cellar is well organized

The wine cellar belongs to a safe and reputable brand

My satisfaction with the wine cellar products/services is the management's most important concern

I'm confident in the wine cellar expertise

My satisfaction with the wine cellar brand is the management's most important concern

I feel good about coming to the wine cellar for the offerings I'm looking for

My feelings towards the wine cellar are very positive

The extent to which the wine cellar has produced the best possible outcome for me is satisfying

Overall I'm satisfied with the wine cellar and the service they provide

I consider this wine cellar my first choice among wineries

I would consider to visit the wine cellar again in the next few years

I would recommend the wine cellar to someone who seeks my advice

I would recommend the wine cellar to family members and close personal friends

I would speak positively of the wine cellar to others

\section{References}

Akaka, M., Vargo, S., Schau, H., 2015. The context of experience. J. Serv. Manag. 26 (2), 206-223.

Alant, K., Bruwer, J., 2004. Wine tourism behaviour in the context of a motivational framework for wine regions and cellars doors. J. Wine Res. 15 (1), 27-37.

Alonso, A., Ogle, A., 2008. Importance of design for small Western Australian wineries. J. Retail Leis. Prop. 7, 139-147.

Anderson, J., Gerbing, D., 1988. Structural equation modelling in practice: a review and recommended two-step approach. Psychol. Bull. 103 (3), 411-423.

Andreev, P., Heart, T., Mauz, H., Pliskin, N., 2009. Validating formative partial least squares (PLS) models: methodological review and empirical illustration. In: Proceedings of ICIS 2009.

Arnould, E., Price, L., 1993. River magic extraordinary experience and the extended service encounter. J. Consum. Res. 20 (1), 24-45.

Backstrom, K., Johansson, U., 2006. Creating and consuming experiences in retail store environments: comparing retailer and consumer perspectives. J. Retail. Consum. Serv. 13, 417-430.

Bagdare, S., Jain, R, 2013. Measuring retail customer experience. Int. J. Retail Distrib. Manag. 41 (10), 790-804.

Bagozzi, R., Yi, Y., 1988. On the evaluation of structural equation models. J. Acad. Mark. Sci. 16, 74-94.

Berry, L., Carbone, P., Haeckel, H., 2002. Managing the total customer experience. MIT Sloan Manag. Rev. 43 (3), 85-89.

Binkhorst, E., Dekker, T., 2009. Agenda for co-creation tourism experience research. J. Hosp. Mark. Manag. 18 (2-3), 311-327.

Bolton, R., Gustafsson, A., Mc-Coll Kennedy, J., Sirianni, N., Tse, D., 2014. Small details that make big differences: a radical approach to consumption experience as a firm's differentiating strategy. J. Serv. Manag. 25 (2), 253-274.
Brown, T., Barry, T., Dacin, P., Guns, R., 2005. Spreading the word: investigating the antecedents of consumer's positive word-of-mouth intentions and behaviours in a retailing context. J. Acad. Mark. Sci. 33 (2), 123-138.

Carù, A., Cova, B., 2003. Revisiting consumption experience: a more humble but complete view of the concept. Mark. Theory 3 (2), 267-286.

Carmichael, B., 2005. Understanding the wine tourism experience for winery visitors in the Niagara region, Ontario, Canada. Tour. Geogr.: Int. J. Tour. Space Place Environ. 7 (2), 185-204.

Chang, T., Horng, S., 2010. Conceptualizing and measuring experience quality: the customer's perspective. Serv. Ind. J. 30 (14), 2401-2419.

Charters, S., Fountain, J., Fish, N., 2009. You felt like lingering: experiencing "real" service at the winery tasting room. J. Travel Res. 48 (1), 122-134.

Dagger, T., Sweeney, J., Johnson, L., 2007. A hierarchical model of health service quality: scale development and investigation of an integrated model. J. Serv. Res. 10 (2), 123-142.

Diamantopoulos, A., Winklhofer, H., 2001. Index construction with formative indicators: an alternative to scale development. J. Mark. Res. 38 (2), 269-277.

Dube, A., Helkkula, A., 2015. Service experiences beyond the direct use: indirect customer use experiences of smartphone apps. J. Serv. Manag. 26 (2), 224-248.

Fornell, C., Larcker, D., 1981. Evaluating structural equation models with unobservable variables and measurement error. J. Mark. Res. 18 (1), 39-50.

Fountain, J., Fish, N., Charters, S., 2008. Making a connection: tasting rooms and brand loyalty. Int. J. Wine Bus. Res. 20 (1), 8-21.

Frow, P., McColl-Kennedy, J., Hilton, T., Davidson, A., Payne, A., Brozovic, D., 2014. Value propositions a service ecosystems perspective. Marketing Theory 14 (3), 327-351.

Frow, P., Payne, A., 2007. Towards the "perfect" customer experience. J. Brand 
Manag. 15, 89-101.

Gentile, C., Spiller, S., Noci, C., 2007. How to sustain the customer experience: an overview of experience components that co-create value with the customer: Eur. Manag. J. 30, 395-410.

Getz, D., Carlsen, J., 2008. Wine tourism among generations X and Y. Tourism: An Interdisciplinary Journal 56 (3), 257-269.

Gilmore, J., Pine II, B., 2002. Customer experience places: the new offering frontier. Strategy Leadersh. 30 (4), 4-11.

Hair, J., Black, W., Babin, B., Anderson, R., 2010. Multivariate Data Analysis. Prentice Hall, Upper Saddle River, NJ.

Hair, J., Hull, G., Ringle, C., Sarstedt, M., 2014. A Primer on Partial Least Squares Structural Equation Modelling (PLS-SEM). SAGE Publications, Thousand Oaks, CA.

Hall, C., Mitchell, R., 2008. Wine Marketing. Butterworth Heinemann, Oxford.

Hall, C., 1996. Wine tourism in New Zealand. In: Kearsley, G. (Eds.) Proceedings of Tourism Down Under II: A Tourism Research Conference. Centre for Tourism, University of Otago, Dunedin.

Han, H., Back, K., 2007. Assessing customers' emotional experiences influencing their satisfaction in the lodging industry. J. Travel Tour. Mark. 23, 43-56.

Han, H., Back, K., Barrett, B., 2009. Influencing factors on restaurant customers' revisit intention: the roles of emotions and switching barriers. Int. J. Hosp. Manag. 28, 563-572.

Helkkula, A., 2011. Characterising the concept of service experience. J. Serv. Manag. 22 (3), 367-389.

Helkkula, A., Kelleher, C., Pihlstrom, M., 2012. Characterizing value as an experience - implications for researchers and managers. J. Serv. Res. 15 (1), 59-75.

Holbrook, M., Hirschman, E., 1982. The experiential aspects of consumption: consumer fantasies, feelings, and fun. J. Consum. Res. 9, 132-140.

Hosany, S., Whitam, M., 2010. Dimensions of cruisers' experiences, satisfaction and intention to recommend. J. Travel Res. 49 (3), 351-364.

Jakkola, E., Helkkula, A., Aarikka-Stenroos, L., 2015. Understanding and advancing service experience co-creation. J. Serv. Manag. 26, 2.

Jarvis, C., MacKenzie, S., Podsakoff, P., 2003. A critical review of construct indicators and measurement model misspecification in marketing and consumer research. J. Consum. Res. 30 (2), 199-218.

Johnston, R., Kong, X., 2011. The customer experience: a roadmap for improvement. Manag. Serv. Qual. 21 (1), 5-24.

Kenningham, T., Cooil, B., Aksoy, L., Andreassen, T., Weiner, J., 2007. The value of different customer satisfaction and loyalty metrics in predicting customer retention, recommendation and share-of-wallet. Manag. Serv. Qual. 17 (4), $361-384$.

Kim, J., Ritchie, J., McCormick, B., 2012. Development of a scale to measure memorable tourist experiences. J. Travel Res. 51 (1), 12-25.

Kim, S., Knutson, B., Beck, J., 2011. Development and testing of the Consumer Experience Index (CEI). Manag. Serv. Qual. 21 (2), 112-132.

Klaus, P., Maklan, S., 2012. EXQ: a multiple-item scale for assessing service experience. J. Serv. Manag. 23 (1), 5-33.

Klaus, P., Maklan, S., 2013. Towards a better measure of customer experience. Int. J. Mark. Res. 55 (2), 227-246.

Knutson, B., Beck, J., Kim, S., Cha, J., 2007. Identifying the dimensions of the experience construct. J. Hosp. Leis. Mark. 15 (3), 31-47.

Lemke, F., Clark, M., Wilson, H., 2011. Customer experience quality: an exploration in business and consumer contexts using repertory grid technique. J. Acad. Mark. Sci. 39, 846-869.

Lusch, R., Vargo, S., 2006. Service-dominant logic: reactions, reflections and refinements. Marketing theory 6 (3), 281-288.

Maklan, S., Klaus, P., 2011. Customer experience: are we measuring the right things? Int. J. Mark. Res. 53 (6), 771-792.

Manthiou, A., Lee, S., Tang, L., Chiang, L., 2014. The experience economy approach to festival marketing: vivid memory and attendee loyalty. J. Serv. Mark. 28 (1), 22-35.

Martin, J., Mortimer, G., Andrews, L., 2015. Re-examining online customer experience to include purchase frequency and perceived risk. J. Retail. Consum. Serv. 25, 81-95.

McColl-Kennedy, J., Cheung, L., Ferrier, E., 2015. Co-creating service experience practices. J. Serv. Manag. 26 (2), 249-275.

Mitchell, R., Hall, C., 2004. The post-visit consumer behaviour of New Zealand winery visitors. J. Wine Res. 15 (1), 39-49.

Morgan, R., Hunt, D., 1994. The commitment-trust theory of relationship marketing. J. Mark. 58 (7), 20-38.

MSI, 2014. MSI (Marketing Science Institute) 2014-2016 Research Priorities. Available at: 〈http://www.msi.org/research/2014-2016-research-priorities/tier-1-un derstanding-customers-and-the-customer-experience/>.

Naylor, G., Keiser, B., Baker, J., Yorktown, E., 2008. Using transformational appeals to enhance the retail experience. J. Retail. 84 (1), 49-57.

Nowak, L., Newton, S., 2006. Using the tasting room experience to create loyal customers. Int. J. Wine Mark. 18 (3), 57-65.

Nunnally, J., 1978. Psychometric Theory, 2nd edition. Mcgraw-Hill, New York.

O'Neill, M., Charters, S., 2000. Service quality at the cellar door: implications for Western Australia's developing wine tourism industry. Manag. Serv. Qual. 10 (2), 112-122.

O'Neill, M., Palmer, A., Charters, S., 2002. Wine production as a service experience: the effect of service quality on wine sales. J. Serv. Mark. 16 (4), 342-362.

Oh, H., Fiore, A., Jeoung, M., 2007. Measuring Experience Economy Concepts: Tourism Applications. J. Travel Res. 46, 119-132.

Oliver, R., 1997. Satisfaction: A Behavioral Perspective on the Consumer. McgrawHill, United States.

Olsson, L., Friman, M., Pareigis, J., Edvardsson, B., 2012. Measuring service experience: applying the satisfaction with travel scale in public transport. J. Retail. Consum. Serv. 19 (19), 413-418.

Palmer, A., 2010. Customer experience management: a critical review of an emerging idea. J. Serv. Mark. 24 (3), 196-208.

Parasuraman, A., Zeithaml, V., Berry, L., 1988. SERVQUAL: a multiple-item scale for measuring consumers perceptions of service quality. J. Retail. 64 (1), 12-40.

Parasuraman, A., Zeithaml, V., Malhotra, A., 2005. E-S-QUAL: a multiple item scale for assessing electronic service quality. J. Serv. Res. 7 (3), 213-234.

Pikkemaat, B., Peters, M., Boksberger, P., Secco, M., 2009. The Staging of Experiences in Wine Tourism. J. Hosp. Mark. Manag. 18 (2-3), 237-253.

Pine II, B., Gilmore, J., 1998. Welcome to the experience economy. Harv. Bus. Rev. 76 (4), 97-105.

Ponsignon, F., Klaus, P., Maull, R., 2015. Experience co-creation in financial services: an empirical exploration. J. Serv. Manag. 26 (2), 295-320.

Poulsson, H., Kale, H., 2004. The experience economy and commercial experiences. Mark. Rev. 4, 267-277.

Prahalad, K., Ramaswamy, V., 2004. Co-creation experiences: the next practice in value creation. J. Interact. Mark. 18 (3), 5-14.

Quadri-Felitti, D., Fiore, A., 2012. Experience economy constructs as a framework for understanding wine tourism. J. Vacat. Mark. 18 (1), 3-15.

Quan, S., Wang, N., 2004. Towards a structural model of the tourist experience: an illustration from food experiences in tourism. Tour. Manag. 25 (3), 297-305.

Ringle, C., Sarstedt, M., Straub, D., 2012. A critical look at the use of PLS-SEM in MIS quarterly. MIS Q. 36 (1), 3-14.

Sandstrom, S., Edvardsson, B., Kristensson, P., Magnusson, P., 2008. Value-in-use through service experience. Manag. Serv. Qual. 18 (2), 112-126.

Schmitt, B., 1999. Experiential marketing. J. Mark. Manag. 15, 56-67.

Shaw, C., Ivens, J., 2005. Building Great Customer Experience. Macmillan, New York.

Slatten, T., Mehmetoglu, M., Svenson, G., Svaeri, S., 2009. Atmospheric experiences that emotionally touch customers: a study from a winter park. Manag. Serv. Qual. 19 (6), 721-746.

Tung, V., Ritchie, J., 2011. Exploring the essence of memorable tourism experience. Ann. Tour. Res. 38 (4), 1367-1386.

Tynan, C., McKechnie, S., 2009. Experience marketing: a review and assessment. J. Mark. Manag. 25 (5-6), 501-517.

Vargo, S., Lusch, R., 2004. Evolving to a new dominant logic for marketing. J. Mark. $68,1-17$.

Vargo, S., Lusch, R., 2006. Service-dominant logic: what it is, what it is not, what it might be. In: Lusch, Robert F., Vargo, Stephen L. (Eds.), The Service-Dominant Logic of Marketing: Dialog, Debate, and Directions. M.E. Sharpe, Armonk, pp. 43-56.

Verhoef, P., Lemon, K., Parasuraman, A., Roggeveen, A., Schlesinger, L., Tsiros, M., 2009. Customer experience: determinants, dynamics and management strategies. J. Retail. 85 (1), 31-41.

Volo, S., 2009. Conceptualizing experience: a tourist-based approach. J. Hosp. Mark. Manag. 18, 111-126.

Walls, R., 2013. A cross-sectional examination of hotel consumer experience and relative effects on consumer values. Int. J. Hosp. Manag. 32, 179-192.

Walls, R., Okumus, F., Wang, Y., Joon, D., Kwun, W., 2011. An epistemology view of consumer experiences. Int. J. Hosp. Manag. 30, 10-21.

Wold, H., 1982. Soft modelling. The basic design and some extensions. In: Joreskog, K., Wold, H. (Eds.), Systems Under Indirect Observation. Causality, structure, prediction. Part I. North-Holland, Amsterdam, pp. 1-54.

Yuan, Y., Wu, C., 2008. Relationships among experiential marketing, experiential value and customer satisfaction. J. Hosp. Tour. Res. 32 (3), 387-410. 